\title{
A study of the role of religious development in childhood on psychological health in Indonesia
}

\begin{tabular}{|c|c|}
\hline \multicolumn{2}{|l|}{$\begin{array}{l}\text { Authors: } \\
\text { A. Akrim }{ }^{1} \text { (D) } \\
\text { Junaidi }^{2} \text { (D) }\end{array}$} \\
\hline \multicolumn{2}{|c|}{$\begin{array}{l}\text { Affiliations: } \\
{ }^{1} \text { Department of Islamic } \\
\text { Religion Education, Faculty of } \\
\text { Islamic Religion, Universitas } \\
\text { Muhammadiyah Sumatera } \\
\text { Utara, Medan, Indonesia }\end{array}$} \\
\hline \multicolumn{2}{|c|}{$\begin{array}{l}{ }^{2} \text { Department of Islamic } \\
\text { Political Thought, Faculty of } \\
\text { Ushuluddin and Islamic } \\
\text { Studies, State Islamic } \\
\text { University of North Sumatera, } \\
\text { Medan, Indonesia }\end{array}$} \\
\hline \multicolumn{2}{|c|}{$\begin{array}{l}\text { Corresponding author: } \\
\text { A. Akrim, } \\
\text { akrim@umsu.ac.id }\end{array}$} \\
\hline \multicolumn{2}{|c|}{$\begin{array}{l}\text { Dates: } \\
\text { Received: } 03 \text { Mar. } 2021 \\
\text { Accepted: } 09 \text { July } 2021 \\
\text { Published: } 11 \text { Nov. } 2021\end{array}$} \\
\hline \multicolumn{2}{|c|}{$\begin{array}{l}\text { How to cite this article: } \\
\text { Akrim, A. \& Junaidi, 2021, 'A } \\
\text { study of the role of religious } \\
\text { development in childhood } \\
\text { on psychological health in } \\
\text { Indonesia', HTS Teologiese } \\
\text { Studies/Theological Studies } \\
77(4), \text { a6584. https://doi. } \\
\text { org/10.4102/hts.v77i4.6584 }\end{array}$} \\
\hline \multicolumn{2}{|c|}{$\begin{array}{l}\text { Copyright: } \\
\text { (C) 2021. The Authors. } \\
\text { Licensee: AOSIS. This work } \\
\text { is licensed under the } \\
\text { Creative Commons } \\
\text { Attribution License. }\end{array}$} \\
\hline \multicolumn{2}{|l|}{ Read online: } \\
\hline 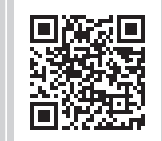 & $\begin{array}{l}\text { Scan this QR } \\
\text { code with your } \\
\text { smart phone or } \\
\text { mobile device } \\
\text { to read online. }\end{array}$ \\
\hline
\end{tabular}

Despite rapid advances in solving human physical problems, medical science has not yet taken effective actions to solve human psychological problems, whilst they play an important role in causing physical diseases. In general, religion significantly affects the health of the individuals and society. Psychological peace may be established through good beliefs and admirable moral deeds, and a believer can be transformed into a lively and happy human being who is always striving and communicating with his community. Therefore, this study aimed at determining the role of religious development in childhood on psychological health at Jakarta, Bandung, Medan and Surabaya in Indonesia. Hence, 3000 children of the above cities were investigated using a simple random sampling method. The statistical analyses using Statistical Package for the Social Sciences (SPSS) indicated that the participants acknowledged the role of religious development in the psychological health of individuals $(p=0.782$; Sig. $=0.000)$. Maintaining the health of the people of the society is one of the most important issues of any country, which should be taken into account from different aspects, including psychological dimensions. The main task of psychological research studies is to ensure mental and psychological health of people in society, and as demonstrated by the results of this study, this is supported by religion, religiosity and a religious atmosphere in society.

Contribution: This research article contributes to the determination of the role of religious development in the psychological health of children from Jakarta, Bandung, Medan and Surabaya in Indonesia.

Keywords: religious development; religion psychology; health; psychological health; Indonesia.

\section{Introduction}

Psychological study of religious development is a field of studying religious subjects, in which changes in the understanding of religious knowledge and its development are examined in the framework of theories of developmental psychology. These studies have shown how human perceptions and emotions of concepts, such as God, the attributes of God, faith, prayer, mosque and resurrection, change throughout lifetime, given the underlying psychological processes (Benson et al. 2005). Researchers in religious development generally select their subjects from children 3 years of age and older; in fact, a period in which language and thought convergence has begun to some extent, and in this field, one can become aware of the child's religious thoughts and emotions through dialogue and obtain information (Paloutzian 2016). Therefore, empirical findings in this area are logically unexpected for children under 3 years of age. Researchers have tried to show the platforms for the formation of religiosity in this period based on psychological principles. Psychologically, Islamic texts raise issues that contribute to the growth of religiosity, especially in childhood, as well as guide a more complete understanding of the religious development in childhood and the ways of forming its original roots. Today, mental health problems have increased dramatically in different societies, and it is expected that in the coming years, mental disorders will become one of the biggest health problems in the world. In this regard, important factors in preventing psychological problems are religion and religiosity. Given that Indonesia is a country where the predominant religion of its citizens is Islam, benefitting from Islamic teachings and developing religiosity amongst citizens, especially children, can play a significant role in the mental health of individuals and society. Accordingly, this study aimed at investigating the role of religious development in the psychological health of Muslim children in Indonesia in 2020. 


\section{Religious development in childhood from the perspective of various researchers}

\section{Attachment behaviour in children's behavioural system and religious formation}

Some researchers have linked the quality of attachment behaviour in childhood to knowing God at an older age. By developing a concept in attachment theory, they provided a framework for understanding the family-child emotional relationship and the child's knowledge of God. The attachment theory focuses on some of the enduring aspects of behaviour (childcare and child-parent attachment), which are the clear translators of the inner world of the 'normal' person, and thus, chooses a forward-looking point of view (ed. Allen 2008). This theory considers attachment behaviour as an instinctive behaviour and one of the basic human needs. Instinctive behaviour is not inherited; inheritance is a potential capacity of enabling the evolution of the behavioural system or enabling strategies based on information received through the organs of the senses from internal or external sources or both (Fowler 1981). The attachment behaviour that exists from the starting point in the child extends to certain faces, persists throughout life, manifests itself in various forms and sometimes occurs under cryptographic forms (correspondence and telephone communication) to provide a contact. This behaviour, which arises from an innate and acquired need, provides the child with two objects: 1 . safety provided by the mother or nurse, which grants the child the opportunity to learn the necessary activities for survival from his or her mother or nurse because his or her behavioural equipment, which has the necessary flexibility, allows him or her to imitate and then take the initiative; 2 . attachment spreads through the life cycles from mothers to relatives and then to strangers, and finally to wider groups, becoming an important factor in personality development. For this social role to be positive, the child must firstly ensure that he or she resumes contact with the mother if desired. Secondly, the child must be able to establish a perfect harmony between his or her true desires and the mother's capacity in responding appropriately to that demand. Thus, attachment has a double action; a supportive action that allows the child to learn the activity necessary for survival because socialisation leads to the development of the child's personality. Attachment behaviour has an effect on the child's cognitive-emotional-behavioural system that affects his or her behaviour throughout their lifetime (Barrett \& Richert 2003). This system is active or at least available as a schematic working model of the attachment relationship. Patrick applied this idea to the child's understanding of God. According to him, in most religions, God is the ideal form of attachment. God seems to be like the perfect parent. God is a parent-like being (verbally or spiritually) who provides security and protection from danger (Bandura 2003).

When the child's parents or religious educators or teachers at school introduce God as the perfect parent, the child's cognitive-emotional-behavioural system is activated, and the child remembers his or her experiences of a mutual relationship with their parents. The child gradually translates these experiences into general concepts and mental images, and subsequently understands the likeness of God to the perfect parents. This understanding does not necessarily correspond to the intent of the parents or educators; however, rather reflects the relationship of the child's past attachment. According to attachment theory, the favourable relationship between the child and religious symbols, such as words and visual arts and objects as part of religious development, becomes meaningful in early childhood, particularly because of parental influence. Attachment theory also provides answers to understanding how adolescents face religious questions and doubts. According to this theory, adolescents' exposure to religious questions and doubts is related to the attachment relationship in childhood. Some researchers suggest several possibilities in this regard: doubts about an insecure attachment relationship with the primary caregiver may lead to the child becoming religious, which takes place in order to gain a reward, meaning that the God is used as a form of attachment that is absent in the mind background. Conversely, children with secure attachment relationships or with non-religious parents become less religious probably for a variety of reasons (Paloutzian 2016).

\section{The semantic structure and value system of parents in religious development of children}

According to another group of researchers, the child's innate talent for adapting to the environment, understanding the object permanence, the emergence of anxiety at 7 and 8 months, and the emergence of a relationship based on trust or distrust between the parent and child are some of the concepts used in explaining and describing how the basic principles and roots of faith are formed. From birth, all human beings carry the hidden talent of 'adapting to the new environment' when they step into the new environment of life. At the same time, this still is not substantive and actual talent. The growth and dynamism of this talent are based on the completion of human development and the type of encounter with the environment. If the desired result is not achieved from this perspective, adaptation to the new environment loses its growth and dynamism. In a situation where the human environment is stable, there is no change and innovation in it, or it does not provoke the objective affairs of man, and does not pose a challenge to him, so most likely his activities and actions will be limited in the pursuit of knowledge. Now, if the quality and continuity of care, nutrition and purity are poor and if there is no person or persons to establish a reciprocal, complementary and trusting relationship with them, the childish mistrust and despair will take the place of trust in the world around them (Benson, Roehlkepartain \& Rude 2003).

As the child grows older, he realises that the objective current affairs are independent of him and even exist when he is out of sight. At 4 months, the baby typically does not seek out hidden objects; '[w]hat is absent will not come to mind'. At the age of 7-8 months, the child is able to make or 
have a mental image of the missing object. It is here that the child steps onto the cognitive path through which he discovers that he is inherently different from those he loves. This cognition is to the extent that he or she feels the need for finding himself or herself as the centre of gravity of the surrounding world in which others are present. The formation of the above two cognitive abilities (understanding the object permanence and self-awareness) provides the basis for the emergence of a new emotional state that is not very desirable (Bering \& Bjorklund 2004). From now on, the child becomes anxious in the absence of his mother or nurse because he or she is afraid that they will not return. The return of the mother or nurse, who calls the baby by name, hugs him or her, and feeds him or her, leads to the formation of a new trait. A new characteristic of a child is trust in the person who cares for him or her and the environment in which he or she grows up. Parent-child interaction within the age range of 7 and 8 months to about 18 months not only expands the relationship of mutual trust and loyalty but also provides the context for the child to experience something much more lasting and beyond. Parents convey trust and loyalty by interacting with the child, and raising and caring for him or her, and for the child, the first experiences about knowing the world around us, how we look at it and how we can relax our lives. Parents present their views on the meaning of life from their perspective. The child acquires a semantic structure and raw images of the centres of value and authority and their value system, long before he or she can use his language, or formulates concepts, or categorises correctly and clearly his or her parents' values and beliefs.

\section{Cultural events and religious development of children}

A group of researchers used another method to show how the basic principles and roots of religiosity are formed in childhood. By examining famous historical figures, they examined the contribution of culture and history to the formation of religiosity. In these studies, the evaluation of individual and collective life was based on the development of analytical and historical methods (Boyatzis 2004):

In general, he shows how the phenomena of the world are realized in different races in different ways according to the psycho-historical dimension, and how personal goals are formed in the context of the goals of his time and in relation to psychohistorical values. (p. 182)

\section{Fundamentals and roots of religiosity in Islam}

The basic principles and roots of religiosity are psychologically the result of all the experiences recorded in the child's psychological system, which have innate and acquired roots. This can be explained in another way, considering the interpretation of the subject of 'God Instinct' and how to explain the relationship between God Instinct and religiosity in the Islamic context. According to the Verse of Covenant (Surah Al-Araf, Ayat 174) and the Verse of Innateness (Surah Ar-Room, Ayat 30), the root of religiosity must be in the natural instinct (as one of the elements of human existence, which the hand of creation has entrusted to him at the time of his creation), not in the result of the experiences recorded in the mental system. According to the Qur'an, environmental experiences and interactions provide only the context for the positive or negative growth and flourishing of natural instinct. The above claim about the roots of religiosity can be proved by stating a few introductions about natural instinct truth, the relationship between the natural instinct and religion, and how it grows and flourishes, which is adapted from the view of Mousavi Khomeini (2012) in his interpretation of the Verse of Innateness (Surah Ar-Room, Ayat 30).

In his interpretation of the Verse of Innateness, Mousavi Khomeini speaks about the meaning of natural instinct truth:

When God created the human, He gave him two natural instincts, one of which has a main side and the other a secondary side: the main natural instinct is the love of absolute perfection and goodness and happiness, which all human beings enjoy, so that not even one can be found who does not realise perfection and is not in love with goodness and happiness according to the principle of nature and instinct, and secondary natural instinct is hatred of imperfection and abhorrence of evil and cruelty. These two natural instincts are in a state where their spirituality and enlightenment remain without being condemned to the laws of nature. If the natural instinct realised nature and was condemned to its precepts, and became unobtrusive to the clergy and its original world, it is the source of all evil, cruelty and misery.

In addition, according to the verses of the Qur'an, the monotheistic nature, although weakened by attention to the material world and its causes, can turn to God again through cosmological argument or the warning of the prophets. The verses that invite man to meditate on natural phenomena seem to prepare him to feel God's hand in nature and to understand God's presence. Accordingly, the roots of religiosity can be traced to the natural instinct, which is aware of religion, and in fact, religion has come to flourish it. In fact, the root of religiosity is the light of God Instinct, which leads man to absolute goodness and beauty in the absence of captivity in the hands of carnal soul and persistence of his spiritual state, as God has created it in human nature. In case of captivity, it causes cruelty and misery to human beings. In other words, the root of religiosity is 'love of absolute perfection and absolute goodness'. God has embedded it in the nature of man. The child enters the world with this capacity, which makes possible the transformation of human beings during their life in this world into two faces, auspicious human beings and avaricious human beings. The philosophy of the origin of religion is to provide the ground for the transformation of man towards happiness, and all religious precepts relating to the prenatal or early childhood period must be interpreted in the same way, meaning that following these commands leads to a positive flourishing in natural instinct, which is the same as absolute love. 


\section{Psychological health}

Mental health represents emotional and psychological health, in a way that a person can use his thinking and abilities, function in a society and meet the normal needs of daily life (Rasulzada \& Dachert 2009). Preventing the development of mental illness and making the mental environment happy and healthy are the basic needs of mental well-being. A person who can overcome the usual pressures of daily life and have an independent life can be introduced as the one with good mental health. The goal of mental health is to achieve inner peace and contentment. Mental health not only explains the cause of disorders but also seeks to prevent mental illness in its broadest sense, with the aim of preventing the occurrence of severe mental illness (Gomes \& Teixeira 2016).

Islamic teachings can be very effective in achieving this goal; for example, the remembrance of God prevents a person from desires and impulses that cause psychological pressure and stress. Doctrines, such as patience, contentment and trust, guarantee the mental health and peace of the pious person. Mental health does not mean physical relaxation and silence, but it has a more general meaning and is affected by the quality of life. Mental health affects the way people think, feel and behave on a daily basis, as well as their ability to cope with stress, overcome life challenges, build relationships and recover from adversity. Strong mental health does not mean the absence of any problems; however, mental and emotional health is a matter beyond getting rid of depression, anxiety or other psychological problems. People with strong mental health have better control over their emotions, and they seem to be energetic and positive and know many ways to increase their mental health (Haque 2004).

Health is related not only to a strong and healthy body but also to a healthy and vibrant soul and mind. It helps us to be resilient to the difficulties and hardships of our lives, and to overcome the dangers and hardships well. For example, as much as we are careful not to catch a cold and our body does not get sick, we must also be careful not to become anxious and helpless in times of hardship and problems and in the various trials that life presents to us, and we must also be able to make strong and stable decisions, control our emotions, and solve our problems in the best and most correct ways (Chang et al. 2019).

\section{Methodology}

The statistical population of this research study consists of 3000 Muslim children from Jakarta, Bandung, Medan, and Surabaya in Indonesia, who were selected using a simple random sampling method. After determining the components of religious development and psychological health, because of the inability of children to complete the questionnaire, children were interviewed on various topics through preprepared questionnaires in the presence of parents, and their answers were obtained. Of these, $72 \%$ were boys and $28 \%$ were girls; $34 \%$ of children were $6-8$ years old, $42 \%$ of children were more than 8 years old and less than 10 years old, and $24 \%$ were less than 11 years old. The received answers were coded from number 1 - strongly disagree - to number 5 strongly agree - and were analysed by SPSS software. Content validity was used to evaluate the validity of the questionnaires. For this purpose, research questionnaires were presented to the faculty members in the fields of psychology, theology, social sciences and behavioural management, and its generalities were approved.

\section{Results}

After reviewing the theoretical literature of the research, the correlation between the variables was investigated.

The research hypothesis states that there is a significant correlation between religious development and psychological health.

$H_{0}: \mathrm{r}=0$

$H_{1}: \mathrm{r} \neq 0$

As shown in Table 1, because the significance level (sig. $=0.000)$ is less than the predicted error value $(0.05)$, so the relationship between the variables is statistically significant, and as the calculated correlation coefficient is equal to 0.782 , the hypothesis $H_{0}$ is rejected and the hypothesis $\mathrm{H}_{1}$ is confirmed. Therefore, with a $95 \%$ confidence interval, it can be concluded that there is a direct and significant correlation between religious development and psychological health. In other words, improving religious development in Muslim children increases psychological health in them and vice versa.

In addition, in this study, one sample $t$-test was used to assess the status of each of the research variables in the study population. In this test, utility is the average of more than the contract value 3 (mean value); SPSS software was used to perform the test. This test determines the status of each of the research variables. Accordingly, suggestions can be made to improve these variables in the study population. Table 2 shows the results of one sample $t$-test.

At the level of analysis of research variables, all values had a significance level of less than 0.05. For these variables, because of the positive values of the $t$-statistic, their value was more than the mean value. It can be said that the value of these variables is more than the mean value of society, and their status is estimated appropriately.

\section{Discussion}

One of the key issues of our society is religious education in the new generation. Religious education means the transfer of

TABLE 1: Pearson test results to analyse the research hypothesis

\begin{tabular}{lcccc}
\hline Variables & $\begin{array}{c}\text { Sample } \\
\text { size }\end{array}$ & $\begin{array}{c}\text { Correlation } \\
\text { coefficient }\end{array}$ & $\begin{array}{c}\text { Error } \\
\text { level }\end{array}$ & $\begin{array}{c}\text { Significance } \\
\text { level }\end{array}$ \\
\hline $\begin{array}{l}\text { Religious development } \rightarrow \\
\text { Psychological health }\end{array}$ & 3000 & 0.782 & 0.05 & 0.000 \\
\hline
\end{tabular}


TABLE 2: One-sample $t$-test results.

\begin{tabular}{|c|c|c|c|c|c|c|c|}
\hline Variables & Mean & Standard deviation & $t$ & Df & Significance level & Mean difference & Status \\
\hline Religious development & 4.11 & 0.542 & 16.47 & 2999 & 0.000 & 0.89 & Acceptable \\
\hline Psychological health & 4.02 & 0.563 & 14.84 & 2999 & 0.000 & 0.98 & Acceptable \\
\hline
\end{tabular}

religious beliefs, attitudes and emotions to the new generation, a generation supposed to become a religious member of our society during the growth process (Boyatzis 2004). This has always been an important goal and motivation of many large, broad and long organisations and institutions that account for a significant portion of the public and government budgets. Despite the importance of this issue in the society, there is still limited knowledge of the quantity and quality of religious education processes and procedures, especially in children, and a less number of research has been conducted in this field. In psychology, the issue of religiosity, and the processes and procedures of religiosity have been considered by researchers. Thus, this study aimed at determining the role of religious development in childhood on psychological health in Indonesia. The findings revealed that the participants acknowledged the role of religious development in the psychological health of individuals ( $p=0.782$; Sig. $=0.000)$.

For nearly a century, researchers have been concerned about the process and stages of a person's familiarity with religion from childhood to adulthood. This tradition of study, along with rigorous field research, has established its own scientific literature in the West. It can be said that most of these psychological studies have had religious implications and motivations for researchers or their society (Boyatzis, Dollahite \& Marks 2006). In many societies, in principle, the main motivations of religious research studies have been the concerns of religious scholars or religious institutions. Therefore, the psychological research studies on the religious development have also emerged in this macro-context.

The responsibility of families in raising their children is one of the most important issues that is relied on in Islam as one of the characteristics of true believers. Newborn baby is like a sapling. Every growing seedling needs specific soil and a certain amount of light, water, shade and sun. Every child grows up well under the right circumstances and with the specific characteristics of these areas whenever possible. Each of the religious instructions conveys a specific message, and was issued for the prevention and treatment of mental illness. In fact, verses and hadiths are formulas to improve life. In general, Islam is not limited to purely matters of worship, such as prayer and fasting. Lack of religious beliefs will lead to anti-religious behaviours by parents followed by their children. Parents' adherence to ethics, of course, in practice and not in speech is the most important channel for transmitting such valuable concepts to the next generation. Therefore, the most important factor in the continuity and permanence of the religious spirit in their children are their parents. If the child observes the execution of religious commands regularly and continuously at home, he or she will have fewer problems to execute them at an older age.

\section{Conclusion}

The question is what role does religious development in childhood play in mental health? Based on the findings, the answer to this question is that religious development is positively correlated with psychological health. Family is one of the contributing factors because the child learns all actions and behaviours from his or her family, including walking, talking, self-confidence and morality; inheritance, environment and nutrition are other factors influencing child's religious development. Islam opposes incorrect education and training, and instead, provides healthy methods for families to raise their children with confidence. Providing the child with the benefits of Islamic education and leading him to pure values are the great goals of man. However, education, society, culture, press and mass media also play a major role in this regard. Childhood is full of amazing, mysterious, fast, deep and impactful developments. Therefore, these changes are of special importance in human life, and paying no attention to them leads to various abnormalities in the child and related systems. However, mental health in childhood is associated with psychological health in adolescence and adulthood. Therefore, this study aimed at providing platforms for strengthening the psychological health of children with respect to religious development, tried to help parents, teachers, professionals and researchers in this field, which should be complemented by future research and the results of which should be expanded.

\section{Acknowledgements Competing interests}

The authors declare that they have no financial or personal relationships that may have inappropriately influenced them in writing this article.

\section{Authors' contributions}

A.A. wrote the article, and J. carried out the analysis.

\section{Ethical considerations}

This article followed all ethical standards for research without any direct contact with human or animal subjects.

\section{Funding information}

This research work received no specific grant from any funding agency in the public, commercial or not-for-profit sectors.

\section{Data availability}

Data sharing is not applicable to this article as no new data were created or analysed in this study. 


\section{Disclaimer}

The views and opinions expressed in this article are those of the authors and do not necessarily reflect the official policy or position of any affiliated agency of the authors.

\section{References}

Allen, H. (ed.), 2008, Nurturing children's spirituality: Christian perspectives and best practices, Wipf and Stock Publishers, Eugene, OR.

Bandura, A., 2003, 'Commentary: On the psychosocial impact and mechanisms of spiritual modeling', The International Journal for the Psychology of Religion 13(3), 167-173. https://doi.org/10.1207/S15327582IJPR1303_02

Barrett, J.L. \& Richert, R.A., 2003, 'Anthropomorphism or preparedness? Exploring children's God concepts', Review of Religious Research 44(3), 300-312. https:// doi.org/10.2307/3512389

Benson, P.L., Roehlkepartain, E.C. \& Rude, S.P., 2003, 'Spiritual development in childhood and adolescence: Toward a field of inquiry', Applied Developmental Science 7(3), 205-213. https://psycnet.apa.org/doi/10.1207/S1532480XADS0703 12

Benson, P.L., Scales, P.C., Sesma, A., Jr. \& Roehlkepartain, E.C., 2005, 'Adolescent spirituality', in K.A. Moore \& L.H. Lippman (eds.), What do children need to flourish: Conceptualizing and measuring indicators of positive development pp. 25-40. https://doi.org/10.1007/0-387-23823-9_3

Bering, J.M. \& Bjorklund, D.F., 2004, 'The natural emergence of reasoning about the afterlife as a developmental regularity', Developmental Psychology 40(2), 217-233. https://psycnet.apa.org/doi/10.1037/0012-1649.40.2.217
Boyatzis, C.J., 2004, 'The co-construction of spiritual meaning in parent-child communication', in D. Ratcliff (ed ), Children's spirituality: Christian perspectives, research, and applications, pp. 182-200, Wipf \& Stock, Eugene, OR.

Boyatzis, C.J., Dollahite, D.C. \& Marks, L.D., 2006, 'The family as a context for religious and spiritual development in children and youth', in E.C. Roehlkepartain, P.E. King, L. Wagener \& P.L. Benson (eds.), The handbook of spiritual development in childhood and adolescence, pp. 297-309, Sage spiritual development in

Chang, P.S., Knobf, T., Oh, B. \& Funk, M., 2019, 'Physical and psychological health outcomes of Qigong exercise in older adults: A systematic review and metaanalysis', The American Journal of Chinese Medicine 47(2), 301-322. https://doi. analysis', The American Journal of
org/10.1142/s0192415×19500149

Fowler, J., 1981, Stages of faith: The psychology of human development and the quest for meaning, Harper \& Row, New York, NY.

Gomes, A.R. \& Teixeira, P.M., 2016, 'Stress, cognitive appraisal and psychological health: Testing instruments for health professionals', Stress and Health 32(2), 167-172. https://doi.org/10.1002/smi.2583

Haque, A., 2004, 'Psychology from Islamic perspective: Contributions of early Muslim scholars and challenges to contemporary Muslim psychologists', Journal of Religion and Health 43(4), 357-377.

Mousavi Khomeini, S.R., 2012, Explanation of the Hadith of the soldiers of wisdom and ignorance, Institute for Compiling and Publishing the Works of Imam Khomeini, Tehran.

Paloutzian, R.F., 2016, Invitation to the psychology of religion, Guilford Publications, New York, NY.

Rasulzada, F. \& Dackert, I., 2009, 'Organizational creativity and innovation in relation to psychological well-being and organizational factors', Creativity Research Journal 21(2-3), 191-198. https://doi.org/10.1080/10400410902855283 